\title{
Exploring the Constraints and Potential Benefits Associated with Family Farming for Livelihood Improvement in Highlands of Pakistan
}

\author{
Raheel Saqib $^{1 *}$, Muhammad Luqman', Saleem Ashraf ${ }^{3}$, Tahir Munir Butt ${ }^{4}$, Abdur Rehman ${ }^{5}$ Imtiaz \\ Hussain $^{6}$ and Muhammad Umer Mehmood ${ }^{2}$
}

${ }^{1}$ Department of Agricultural Extension Education and Communication, The University of Agriculture Peshawar, Khyber Pakhtunkhwa, Pakistan; 'Department of Agricultural Extension, College of Agriculture, University of Sargodha, Pakistan; ${ }^{3}$ In-service Agricultural Training Institute, Rabim Yar Khan, Pakistan; ${ }^{4}$ Department of Agricultural Extension, UAF Sub Campus Depalpur, Okara, Pakistan; ${ }^{5}$ Department of Agricultural Economics, Faculty of Agriculture, Gomal University D.I. Khan, Pakistan; 'Department of Animal Sciences, College of Agriculture, University of Sargodha, Pakistan.

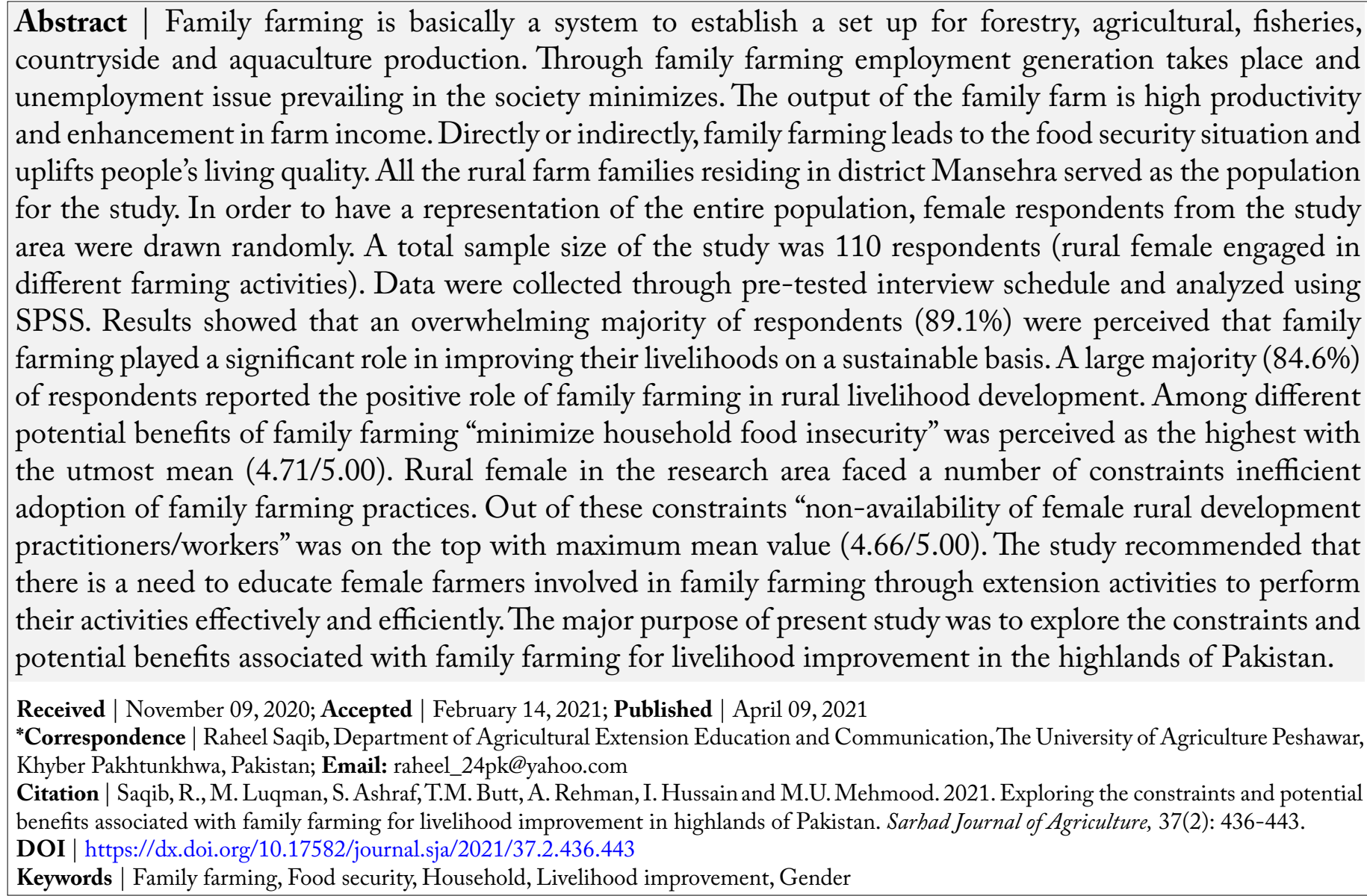

\section{Introduction}

$\mathrm{F}$ amily farming is exposed to terrible political, social, economic and ecological changes. To make sure the progress at the intra-family level and long term survival of their farms; farm families need to adopt innovative, sustainable and market driven strategies (Suess-Reyes and Fuetsch, 2016). Agriculture in the developing world has a low productivity rate relative to the rest of the economic domains (Gollin,

June 2021 | Volume 37 | Issue 2 | Page 436 
2010). So far, till now average land size in Pakistan is 2.5 acres (Rehman et al., 2016). Political reformation has caused a reduction in support for this sector. Changes are also occurring on the demand side; food safety measure and quality standards are being more tightened. Technological shifts, ever-changing social values, environmental disasters and climate change as a whole has the serious consequences for the family farming (Lankester and Brimblecombe, 2012). The leaching down effect of these changes also creates the challenges for family farming at small scale (Garner and de la O Campos, 2014). This situation could be undoubtedly forcing hurdles to the livelihood improvement in the highland areas as well.

Farm income is an essential parameter to estimate the capacity of the family farm. For reaching the goal of national food security, farm incomes could be a valuable addition by the family farms. Gender effects, land rights and economic value at a family farm are three big role-playing phenomenon for food security at a local level (Schleifer and Sun, 2020). In the regional scope of the family farms, high-quality crops, and high nutritional value products are very important. This will enable the family farms to alleviate poverty at an individual farm level by increasing the farm income (Nikolova, 2020). For this reason, provision of skills to the owners of the family farms could be an asset to the impoverished situation for them. Skills regarding record keeping, decision-making, and choosing more sustainable and environment-friendly options should be prioritized (Kagotho et al., 2019). Farm resource management (FRM) is an approach that could be an addition to adopting skilled-based operations at the farm. For those problems that FRM face like; poor knowledge on resource management at farm level, lack of storage facility, lack of farm machinery, and labour crisis are the prominent ones that need special attention by the public sector of extension (Halder et al., 2019). Diversified production of vegetable crops and staple food at regional family farms, can be a worthy initiative to stabilize the economic situation of the individual family farm and food security situation at a wider range (Wittman et al., 2017). This approach of taking the initiative from ground to national level is well explained by Swanson and Rajalahti (2010) as illustrated in Figure 1.

Another more evidently associated factor of women in Khyber Pakhtunkhwa, they participate very little, especially outside from their houses due to socio-cul- tural norms and its purdah rigid society. However, women take part almost in all on-farm operations except ploughing in arid zones, hilly areas and tribal belts (Khan et al., 2012). In Pakistan, the women's contribution to the farm sector can be measured from the time spent percentage during agricultural activities. For example, in cotton and rice-growing areas in Sindh, women spent $50.42 \%$ and $39.34 \%$ of man-day per annum, respectively (Qadri and Akbar, 1982).

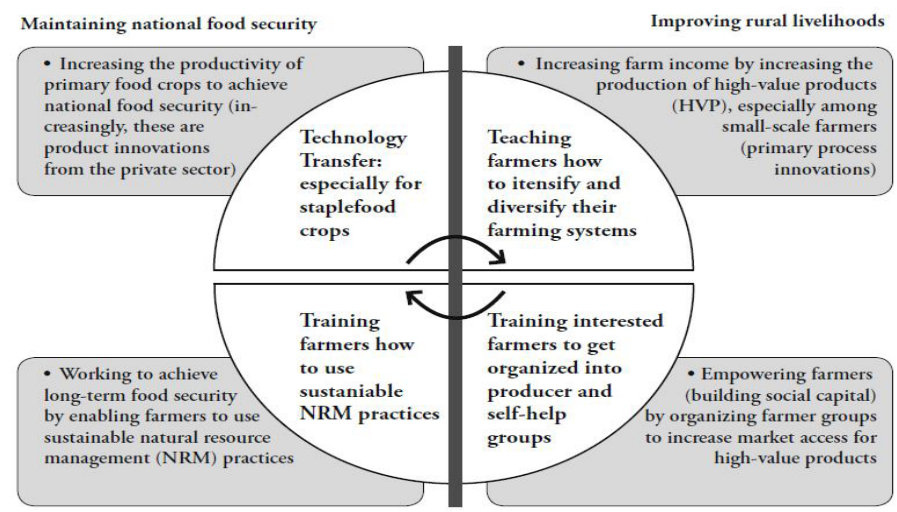

Figure 1: Key functions of extension in achieving specific national agricultural goals.

Family farming is basically a system to establish a set up for forestry, agricultural, fisheries, countryside and aquaculture production. This setup is supervised, manage and run by a family. Household labour, including men and women, mainly run the farming circle. The farm and family has the link which combines, co-evolve environmentally, socially and economically (FAO, 2015).

Peter (2008) researched the benefits and multiple functions of small landholding agriculture. To provide good quality food of adequate quantity to the people is the foremost benefit of family farming. He said that farming managed natural resources and minimized environmental pollution. It opens the gates for the employment for peasants and other rural workers who could not engage themselves in non-agricultural activities. It minimized conflicts and created a peaceful environment. This triggered the authors to highlight the constraints associated with family-farming so that a better farming environment could be ensured for female farmworkers. Besides that, finding out the potential areas contributing to family farming was on this study's agenda. The major purpose of present study was to explore the constraints and potential benefits associated with family farming for livelihood improvement in the highlands of Pakistan. 
Materials and Methods

The present study was conducted in a high land region of Pakistan. The region is commonly known as NorthWest region and presently as Khyber Pakhtunkhwa province of Pakistan. The region is very much famous for the variety of fruits and vegetable production. All the rural farm families residing in district Mansehra served as a population for the study. In order to have a representation of the entire population, female respondents from the study area were selected randomly. Through a simple random sampling technique, two tehsils were selected. Two union councils were selected randomly from each tehsil. From each selected union council, 2 villages were also selected randomly. From each village, 13 women respondents involved in farming activities were selected at random, thereby making a sample of 104 respondents. For more generalization of the sample, this size was increased to 110 female respondents.

Keeping in view the study's specific objectives, an interview schedule was designed to collect the required information. Five Point Likert type scale (1=strongly disagree, 2 =disagree, $3=$ undecided, $4=$ agree, $5=$ strongly agree) was used to record opinions of respondents. The interview schedule was originally prepared in English, which was later on translated into local language Urdu. Due to the research area's cultural and social values, it was difficult for the researchers to collect data from the field during a survey by themselves. For this purpose, a data collection team was constituted of post graduate students of the Department of Agricultural Extension, University of Agriculture, and Peshawar.

For the analysis of the data, Statistical Package for Social Sciences (SPSS) was used. Uni-variate analysis such as percentage, central tendency measures (mean, standard deviation) and frequency was used to describe the data. So, descriptive/univariate statistics were used to calculate, interpret and discuss, draw conclusions, and formulate the recommendations.

\section{Results and Discussion}

\section{Demographic characteristics}

Age: It is generally believed that the individual becomes mentally mature and become independent with the increase in age. Therefore, age can be one of the important factors affecting the decision-mak- ing power of the respondents. The respondents were asked about their age and based on their responses, the table classified age as minimum and maximum. The data regarding this aspect are given in Table 1.

Table 1: Distribution of respondents according to their age.

$\begin{array}{lll}\text { Minimum age } & \text { Maximum age } & \text { Mean age } \\ 25 \text { Years } & 75 \text { Years } & \text { 39 Years }\end{array}$

Out of 110 women respondents, the minimum age of females was 25 years, the maximum age was 75 years, and most of the female respondents had a mean age of 39 years. So, it is obvious from the above results that middle-aged (above 35-50) women are mostly involved in family farming activities for ensuring household food security as compared to young (up to 35 ) or old (above 50) women.

Education: Education means a number of years of schooling, and it is the total of all the processes for bringing about desirable change in human behavior (Memon, 1993). Education develops knowledge and other desirable qualities of mind and general competence, especially by means of formal schooling. It is a fact that an educated person is expected to be analytical and logical towards things. Keeping these facts in view, the present research, therefore, attempted a probe into the respondents' educational level. The information in this respect is given in Table 2.

Table 2: Distribution of respondents according to their education.

$\begin{array}{lll}\text { Educational level } & \text { Number of respondents } & \text { Percentage } \\ \text { Illiterate } & 47 & 42.7 \\ \text { Primary } & 29 & 26.4 \\ \text { Middle } & 18 & 16.4 \\ \text { Secondary } & 16 & 14.5 \\ \text { Total } & 110 & 100\end{array}$

It is evident from the data embodied in Table 2 that the majority of the female $(42.7 \%)$ in the research areas were illiterate. Only few (14.5\%) of respondents had secondary (up to 10 years of schooling). This is unfortunate and disappointing that still in most rural areas of highlands of Pakistan, widespread illiteracy is present. A number of factors are responsible for this high level of illiteracy in rural female in the area. Social security for female and non-availability of schools and colleges at the village level are the major ones. 
Perceived role of family farming in uplifting rural livelihoods

The respondents were asked to give their opinion or perception about family farming's role in uplifting rural livelihoods on a sustainable basis. The respondents response was assessed in the form of dichotomous data (yes) and (no). The data in this regard is tabulated in Table 3.

Table 3: Percentage distribution of respondents regarding the role of family farming in uplifting rural livelihoods as perceived by respondents.

\begin{tabular}{|lll}
$\begin{array}{l}\text { Perceived role of family farming } \\
\text { in uplifting rural livelihoods }\end{array}$ & $\begin{array}{l}\text { Number of } \\
\text { Respondents }\end{array}$ & $\begin{array}{l}\text { Percent- } \\
\text { age }\end{array}$ \\
\hline Yes & 98 & 89.1 \\
No & 12 & 10.9 \\
Total & 110 & 100.0
\end{tabular}

During data collection, a large majority of the respondents said that as the agricultural land is going to be decreasing day by day due to land fragmentation and already, we have small landholdings. We used to do subsistence farming. In this situation of small agricultural landholdings, a large number of respondents said that family farming is the best solution to combat poverty and household food insecurity situation, particularly in the research areas. As the data presented in Table 1 clearly indicated that family farming plays a role in uplifting rural livelihoods, the respondents were further asked to give response regarding potential benefits of family farming through which family farming plays a role in upgrading rural poor's livelihoods.

The respondents were further asked to assess the role of family farming in uplifting rural livelihoods and food security situation at the household level as positive or negative, and the data in this regard is given in Table 4.

The data given in Table 4 shows that a very high majority of the respondents $(84.6 \%)$ responded and reported the positive role of family farming in uplifting rural livelihoods and improving food security situation at the household level. However, few (15.4\%) of the respondents reported a negative role of family farming in uplifting rural livelihoods and also in improving food security situation at the household level. This shows the potential of family farming in improving the livelihood status of rural households.
Table 4: Distribution of respondents according to their perception about the role of family farming in uplifting rural liveliboods.

$\begin{array}{lll}\begin{array}{lll}\text { Role of family farming in } \\ \text { uplifting rural livelihoods }\end{array} & \begin{array}{l}\text { Number of } \\ \text { Respondents }\end{array} & \text { Percentage } \\ \text { Positive } & 83 & 84.6 \\ \text { Negative } & 15 & 15.4 \\ \text { Total } & 98 & 100.0\end{array}$

Potential benefits of family farming as perceived by respondents

Family farming is basically a system to establish a set up for forestry, agricultural, fisheries, countryside and aquaculture production. This setup is supervised, manage and run by a family. Household labour, including men and women, mainly run the farming circle. The farm and family is the link between environmental, society and economics (FAO, 2015).

There are many potential benefits of family farming as perceived by respondents. Cost-saving, labour saving, increase in profit, increase management, increase management, increase production and minimize household food insecurity were considered as potential benefits and enlisted for the present study. The respondents were asked about these benefits, and the data regarding this aspect are presented in Table 5.

Table 5: Distribution of activities based potential benefits of family farming as perceived by women.

$\begin{array}{lll}\text { Activity-based potential benefits } & \text { Mean } & \text { SD } \\ \text { Cost-saving } & 4.60 & 0.492 \\ \text { Labour saving } & 4.53 & 0.520 \\ \text { Increase in profit } & 4.55 & 0.552 \\ \text { Increase management } & 4.62 & 0.635 \\ \text { Increase production } & 4.45 & 0.568 \\ \text { Minimize household food insecurity } & 4.71 & 0.454\end{array}$

The data tabulated in Table 5 reveals that minimize household food insecurity was considered as potential benefit fell in the range of agree and strongly agree categories with mean value 4.71 . Increase management cost saving and increase in profit recorded between strongly agree and agree categories with the mean values 4.62/5.00, 4.60/5.00 and 4.55/5.00, respectively. Labour-saving and increase production were the benefits fell in between agree and strongly agree with having mean value $4.53 / 5.00$ and $4.45 / 5.00$, respectively. The results showed that family farming was very much beneficial for raising rural livelihoods and 
helping in minimizing household food insecurity.

\section{Constraints faced by females regarding work at the farm} Rural females participated in family farming activities for securing livelihoods. But due to cultural boundaries, women faced constraints regarding work at the farm. Keeping in view this aspect, the respondents were asked about their problems they had faced during work at the farm. Activities based on constraints were listed in Table 6 and scaled selected ranging from 1 to 5 categorized as agree, strongly agree, undecided, disagree and strongly disagree.

The data tabulated in Table 6 depicted that all the constraints fell between agree and strongly agree categories with different mean values. Burden of household work was one of the major constraints faced by females having a mean value of 4.92/5.00. The constraints faced by rural females included non-availability of female rural development practitioners/workers, dominant male society and social structure, lack of social security and lack of access to agriculture extension services having mean values 4.66, 4.64, 4.60 and 4.59, respectively. Agricultural extension staff must have easy access to farmers for timely technology transfer (Safdar et al., 2016). Lack of transport facilities, lack of access to agriculture information sources and lack of access to agriculture education and training facilities were having the same mean value (4.57/5.00).

The constraints like low farm wages, lack of property rights and low literacy level of females having the same mean value (4.53/5.00). Lack of access to computer-related information delivery and exchange system, child care and gender violence constraints faced by rural females having the same mean value (4.52/5.00).Limited public and private sector outreach activities, lack of support and encourage of women in group fieldwork, lack of incentives for rural women to participate in farm practices, financial assistance, lack of provision of agricultural credit facilities and lack of authority in decision making regarding farm practices and daily house life were constraints with having mean values 4.51/5.00, 4.50/5.00, 4.49/5.00, 4.48/5.00, 4.47/5.00 and 4.46/5.00, respectively. Reorganization and appreciation of women work, traditional belief system, mobility issues, and technical assistance were limitations faced by rural women with having mean value 4.45/5.00, 4.45/5.00, 4.45/5.00 and $4.38 / 5.00$, respectively.
Table 6: Distribution of activities based on constraints faced by females regarding work at the farm.

\section{Constraints}

Mean SD

Non-availability of female rural development 4.66 0.475 practitioners/workers

Male dominant society and social structure 4.64

Lack of social security

$4.60 \quad 0.492$

Traditional belief system

$4.45 \quad 0.499$

Burden of house-hold work

$4.92 \quad 3.793$

Child care

$4.52 \quad 0.502$

Lack of transport facilities

4.57

0.497

Lack of access to agriculture extension services

Lack of access to agriculture information

$4.59 \quad 0.512$

sources

Lack of access to agriculture education and

\section{training facilities}

$\begin{array}{ll}4.57 & 0.497\end{array}$

Lack of access to computer-related information 4.52 delivery and exchange system

Low farm wages

4.53

Lack of authority in decision making regarding 4.46 0.501 farm practices and daily house life

Lack of support and encourage women in group $4.50 \quad 0.502$ fieldwork

Lack of land property rights

$4.53 \quad 0.502$

Reorganization and appreciation of women

$4.45 \quad 0.500$ work

Gender violence

$4.52 \quad 0.502$

Lack of provision of agricultural credit facilities $4.47 \quad 0.520$

Lack of incentives for rural women to

$4.49 \quad 0.502$ participate in farm practices

Limited public and private sector outreach

$4.51 \quad 0.520$ activities

Low literacy level of female

$4.53 \quad 0.520$

Technical assistance

$4.38 \quad 0.663$

Financial assistance

$4.48 \quad 0.537$

Mobility issues

$4.45 \quad 0.536$

Potential role of family farming in poverty reduction: $A$ qualitative analysis

During discussion with the members of families in the study area, the data collection team came up with various responses about family farming as a potential source of income. Here, we would like to mention 03 views among the many, which have a realistic approach. Firstly, when a family asked about the potential benefits of the family farming they said;

We are our own supervisors, and we can set our own working hours keeping in view the farm situation and the tasks which require daily base attention. Multiple 
tasks can be carried out at the same time by dividing the associated activities. It also generates a sense of responsibility in a family as a whole and brings the satisfaction of producing our own food.

From their views, it is clear that they enjoy being their own boss and setting their working hour accordingly. Division of work among the different family members is another blessing they enjoy. Conclusively they experienced that their farm makes them a responsible individual. Di-Domenico and Miller (2012) found that family farming has an exceptional contribution in making a farmer independent what he does. Having food grown by them also brings satisfaction to mind and great health benefits. These all benefits only get enjoyed the owners of family farms. In addition to this second response from a family owing a family farm was quiet animal-oriented;

At our farm animals are considered as part of the family, and this phenomenon requires lots of patience. They get well care and could avoid the routine of the antibiotics injections compared to the farms handled at commercial levels and open farms. In our opinion, happy and healthier animals mean a happy and healthy family or consumers.

This family owing family farm stated that they use to take their farm animals as part of their family. Most interesting thing stated by them is that they get to develop a factor of patience due to this. Keeping in view the health of animals and humans as well they treat their animals with traditional care instead of the conventional or commercial one. Moreover, there is evidence of long-term health effects on the ruminants and consumers as well, if the livestock is treated with antibiotics regularly (Oliver et al., 2011). They associated the health of society with the health of animals that society own. Thirdly the views of a family about owing a family farm were more oriented to learning.

Learning at the farm has multiple benefits, including setting the practical knowledge base. Our generation will learn the maximum by working at our farms. Learning through agricultural techniques at our farm explicate us about the many other things like; genetics, environment and management.

They highlighted the learning phenomenon by doing farm work at their family farm. In this way, they also prioritized the learning by practical effort. They claimed that they get to know about the genetic qualities of different varieties in the same crop. They get well understand the environment and management of time and task is also an extra benefit they learn at the family farm. Gender values, farm practices and decision-making qualities interference at family farm enable the practitioner with maximum and quality learning without any cost (Carnegie et al., 2020). There is no doubt that countless applications about which an individual from the family-owned family farm can learn. This clarifies that family farm is blessing either on a wider level or at a short level.

\section{Conclusions and Recommendations}

It was concluded that the average age of respondents in the study area was 39 years. Educational status of respondents was very low as the majority of the respondents were found illiterate. It was concluded that out of different potential benefits of family farming, "minimize household food insecurity" was at the top with maximum mean 4.71/5.00. The results concluded that family farming was very much beneficial for raising rural livelihoods and helping in minimizing household food insecurity. All the constraints faced by rural females fell between agree and strongly agree categories with different mean values. Lack of transport facilities, lack of access to agriculture information sources and lack of access to agriculture education and training facilities were having the same mean value, i.e. 4.57/5.00. The constraints like low farm wages, lack of property rights and low literacy level of females having the same mean value, i.e. 4.53/5.00. Lack of access to computer-related information delivery and exchange system, child care and gender violence constraints faced by rural females having the same mean value of 4.52 .

The study recommended that there is a need to educate female farmers and skill development involved in family farming. This could be achieved by involving local extension departments, so their activities could be made effective and efficient. For this purpose, training should be arranged for women at the community level through female trainers. Rural females are participating in family farming activities for securing their livelihoods. But due to cultural boundaries, women are facing so many constraints regarding work at the farm. Government sector, NGOs, and policy makers should focus on the constraints faced by rural women and should take positive actions. 


\section{Acknowledgements}

The authors highly acknowledged the financial support provided by Higher Education Commission (HEC), Islamabad under NRPU research project \# 10499 for completing this manuscript.

\section{Novelty Statement}

Constraints to the family farming where females are main role player have been ignored by the researcher community. This is an effort of finding the constraints alongside the potential benefits entangled with family farming in an area where values and norms are of critical importance.

\section{Author's Contribution}

Raheel Saqib: Conceived the idea of research as principal author and finalized the manuscript.

Muhammad Luqman: Prepared initial draft of manuscript.

Saleem Ashraf: Reviewed the literature.

Tahir Munir Butt: Prepared research instrument.

Abdur Rehman: Data analysis.

Muhammad Umer Mehmood and Imtiaz Hussain:

Field data collection.

\section{Conflict of interest}

The authors have declared no conflict if interest.

\section{References}

Carnegie, M., P.S. Cornish, K.K. Htwe and N.N. Htwe. 2020. Gender, decision-making and farm practice change: An action learning intervention in Myanmar. J. Rural Stud., 78: 503-515. https://doi.org/10.1016/j.jrurstud.2020.01.002

Di Domenico, M. and G. Miller. 2012. Farming and tourism enterprise: Experiential authenticity in the diversification of independent smallscale family farming. Tour. Manag., 33(2): 285-294. https://doi.org/10.1016/j.tourman.2011.03.007

FAO, 2015. State of Food and Agriculture (SOFA). Livestock in the balance. FAO, Rome, Italy.

Garner, E. and A.P. de la O Campos. 2014. Identifying the family farm; an informal discussion of the concepts and definitions. https://ageconsearch.umn.edu/record/288978/

Gollin, D., 2010. Agricultural productivity and eco- nomic growth. Handbook of Agric. Econ., 4:

3825-3866. https://doi.org/10.1016/S15740072(09)04073-0

Halder, S.K., M.N. Uddin and M.J. Hoque. 2019. Training need of the farmers on-farm resource management: A case of North-Eastern region in rural Bangladesh. Bull. Inst. Vocat. Tech. Educ., Graduate Sch. Educ. Hum. Dev., Nagoya Univ. Japan. 19: 61-72.

Kagotho, N., N.N. Salim, M. Patak-Pietrafesa and S. Kyriakakis. 2019. Inheriting the family farm: Generational wealth transfers in rural Kenya. Dev. Policy Rev., https://doi.org/10.1111/ dpr.12457

Khan, M., M. Sajjad, B. Hameed, M.N. Khan and A.U.Jan. 2012. Participation of women in agriculture activities in district Peshawar. Sarhad J. Agric., 28(1): 121-127.

Lankester, P. and P. Brimblecombe. 2012. The impact of future climate on historic interiors. Sci. Total Environ., 417: 248-254. https://doi. org/10.1016/j.scitotenv.2011.12.026

Memon, P.A. and D. Lee-Smith. 1993. Urban Agriculture in Kenya, Canadian J. Afr. Stud., 27(1): 25-42. https://doi.org/10.1080/0008396 8.1993.10804310

Memon, S., 1993. Impacts of land reform on farm production and income distribution in the agricultural sector of Sindh Province of Pakistan (Doctoral dissertation, Texas Tech University). http://hdl.handle.net/2346/11873

Nikolova, M., 2020. Opportunities and challenges in the sale of agricultural products from small and family farms in Bulgaria. Trakia J. Sci., 18(1): 549-559.

Oliver, S.P., S.E. Murinda and M. Jayarao. 2011. Impact of antibiotic use in adult dairy cows on antimicrobial resistance of veterinary and human pathogens: A comprehensive review. Foodborne Pathog. Dis., 8(3): 337-355. https://doi.org/10.1089/fpd.2010.0730

Peter, R., 2008. The multiple functions and benefits of small farm agriculture. Institute of food and development policy. http://www.agter.org (assessed on 10-11-15).

Qadri, S.M.A. and J. Akbar. 1982. Women in agriculture. Sindh Women's Division. Govt. of $\mathrm{Pa}-$ kistan. pp. 239-245.

Rehman, T., M.U. Khan, M. Tayyab, M.W. Akram and M. Faheem. 2016. Current status and overview of farm mechanization in Pakistan. A re- 
view. Agric. Eng. Int. CIGR J., 18(2): 83-93.

Safdar, U., S. Ali and M.T. Siddiqui. 2016. Access to agricultural information as perceived by farmers: Insights from Punjab, Pakistan. J. Agric. Res., 54(3): 573-582.

Schleifer, P. and Y. Sun. 2020. Reviewing the impact of sustainability certification on food security in developing countries. Glob. Food Sec., 24: 100337. https://doi.org/10.1016/j. gfs.2019.100337

Suess-Reyes, J. and E. Fuetsch. 2016. The future of family farming: A literature review on innovative, sustainable and succession-oriented strategies. J. Rural Stud., 47: 117-140. https://doi. org/10.1016/j.jrurstud.2016.07.008
Swanson, B.E. and R. Rajalahti. 2010. Strengthening agricultural extension and advisory systems. World Bank, Washington, DC, USA

Swanson, B.E., 2009. Changing extension paradigms within a rapidly changing global economy. In: Proceedings of the $19^{\text {th }}$ European seminar on extension education: Theory and practice of advisory work in a time of Turbulences. pp. 113-117.

Wittman, H., M.J. Chappell, D.J. Abson, R.B. Kerr, J. Blesh, J. Hanspach and J. Fischer. 2017. A social-ecological perspective on harmonizing food security and biodiversity conservation. Reg. Environ. Change, 17(5): 1291-1301. https://doi.org/10.1007/s10113-016-1045-9 